\title{
IBN KHALDUN, LIFE AND TIMES
}




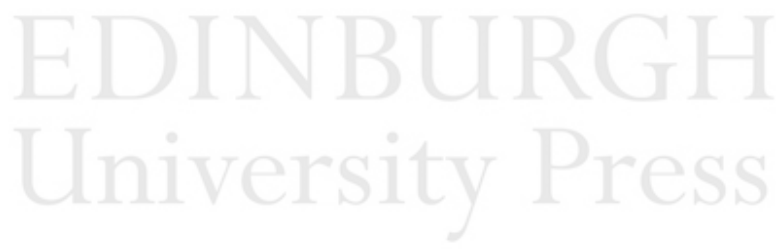

Not for distribution or resale. For personal use only. 


\section{IBN KHALDUN, \\ LIFE AND TIMES}

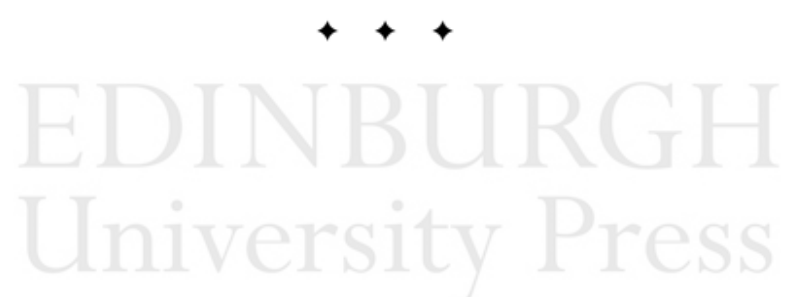

ALLEN JAMES FROMHERZ

Edinburgh University Press 
(C) Allen James Fromherz, 2010

Edinburgh University Press Ltd

22 George Square, Edinburgh www.euppublishing.com

Typeset in JaghbUni by

Servis Filmsetting Ltd, Stockport, Cheshire, and

printed and bound in Great Britain by

CPI Antony Rowe, Chippenham and Eastbourne

A CIP record for this book is available from the British Library

ISBN 9780748639342 (hardback)

The right of Allen James Fromherz to be identified as author of this work has been asserted in accordance with the Copyright, Designs and Patents Act 1988. 